\title{
KRYZYS CZY NOWY ETAP ROZWOJU? Z BADAŃ NAD PRZEOBRAŻENIAMI PIASTOWSKICH OŚRODKÓW GRODOWYCH W XII I XIII WIEKU - PRZYKLADY KRUSZWICY I LĄDU NAD WARTĄ
}

\author{
A CRISIS OR A NEW STAGE OF DEVELOPMENT? \\ RESEARCH INTO THE TRANSFORMATION OF STRONGHOLD DURING \\ THE REIGN OF THE PIAST DYNASTY IN THE $12^{\text {TH }}$ AND \\ $13^{\mathrm{TH}}$ CENTURIES, EXAMPLES OF KRUSZWICA AND LĄD NAD WARTĄ
}

\begin{abstract}
The article presents the transformation of stronghold in Poland in the $12^{\text {th }}$ and $13^{\text {th }}$ centuries. By providing the examples of Kruszwica (Kuyavia) and Ląd (Wielkopolska), attention has been drawn to the fact that, despite the collapse of the strongholds around which gords were once organised, they could continue development and remain political, societal, religious, economic and cultural centres. They allow historians to take a different view of the operations of the then territorial and administrative organisation in Poland as well as the gradual disintegration of the system.
\end{abstract}

Keywords: Middle Ages, gord, centre, Kruszwica, Ląd, territorial and administrative organisation, town.

W nurt różnorodnych przemian zachodzących na ziemiach polskich w XII i XIII wieku wpisały się przeobrażenia ośrodków grodowych, powstałych w większości w okresie funkcjonowania pierwszego państwa piastowskiego. Szereg symptomów tego zjawiska, odkrywanych w źródłach archeologicznych, wskazuje na tendencje odchodzenia od związanego z nimi systemu zarządu terytorialnego i kształtowania się nowej jakości, która stała się zaledwie etapem w przejściu do nowocześniejszych form organizacji osadnictwa, odpowiadającej aktualnym potrzebom z zakresu administracji i obronności, a także wpisującej się w rytm życia gospodarczego i społecznego oraz w aktywizację działań na rzecz upowszechniania kultu i wartości religii chrześcijańskiej. Na ten interesujący moment rozłożonego w czasie procesu zwrócił uwagę Wojciech Dzieduszycki (1984; 2008; 2015)

* ORCID 0000-0001-7254-9236, Muzeum Archeologiczne w Poznaniu, ul. Wodna 27, 61-781 Poznań, e-mail: michal.brzostowicz@muzarp.poznan.pl. 
w swych studiach nad dziejami średniowiecznej Kruszwicy. Rozpoznajemy go również w Lądzie nad Wartą, który wymaga teraz innego spojrzenia od zaproponowanego we wcześniejszych artykułach (m.in. Brzostowicz 2005; 2011; 2015a). Wybrane przypadki odsłaniają ciekawy aspekt dziejów piastowskich ośrodków grodowych w XII i XIII wieku, skłaniając jednocześnie do zastanowienia się nad pytaniem, czy ilustrują one sugerowany przez wielu badaczy kryzys, czy może stanowią świadectwo innych form rozwoju?

W przekonaniu Wojciecha Dzieduszyckiego (2008, s. 411; 2015, s. 74), momentem inicjującym przeobrażenia ośrodka kruszwickiego była bitwa stoczona w 1096 roku w pobliżu tamtejszego grodu między wojskami księcia Władysława Hermana a hufcami jego syna Zbigniewa. Klęska buntownika, wspieranego przez miejscową załogę, wedle relacjonującego wydarzenie kronikarza (Gall, ks. II, rozdz. 5) zmieniła opływającą w bogactwa Kruszwicę w pustynię. Nie trwało to długo, ponieważ w stosunkowo krótkim czasie nastąpiła odbudowa tego ośrodka, który zarazem zyskał nowy charakter. W poważnym stopniu wpłynęła na to rozbiórka fortyfikacji grodowych oraz przekształcenie warowni w osiedle otwarte o charakterze rzemieślniczym. Zdaniem W. Dzieduszyckiego, w opisanych działaniach należy upatrywać sankcji zwycięskiego władcy wobec miejscowej ludności, nałożonych za jej udział w buncie niepokornego juniora. Sądząc z posadowienia w miejscu zniwelowanych wałów obiektów mieszkalnych i produkcyjnych, demilitaryzacja Kruszwicy miała znamiona nieodwracalności. Nie zahamowała bynajmniej jej rozwoju, raczej nadała mu nowy wymiar. Nastąpił rozrost aglomeracji osadniczej, która objęła wschodni brzeg Gopła, pozostający dotąd poza strefą zwartego zasiedlenia (ryc. 1). Być może dokonało się to kosztem innych osiedli funkcjonujących w regionie, skąd prawdopodobnie przeniesiono ludność do omawianego ośrodka (Dzieduszycka 1995, s. 78), nieco opuszczonego po burzliwych wydarzeniach 1096 roku. W opinii W. Dzieduszyckiego (1982, s. 118 i nn.; 2015, s. 76), odbiciem owych przemieszczeń był pewien regres $\mathrm{w}$ garncarstwie, spowodowany odpływem profesjonalnych wytwórców i zastąpieniem ich przez wiejskich rękodzielników, kultywujących archaiczne techniki produkcji. Jednak pozostałe dziedziny rzemiosła rozwijały się w sposób dynamiczny, a działalność warsztatów produkujących wyroby złotnicze, szklarskie, grzebiennicze, czy też gliniane płytki posadzkowe wskazuje na znaczny rozwój gospodarczy Kruszwicy. Istotnym czynnikiem, kształtującym jej koniunkturę już w X i XI wieku, było dogodne położenie przy ważnych szlakach komunikacyjnych, dzięki czemu mogła funkcjonować jako ważny ośrodek handlu i wymiany. Świadectwem ówczesnego znaczenia Kruszwicy jest obecność wyrobów wywodzących się z zachodnioeuropejskiego, pomorskiego oraz rusko-bizantyjskiego kręgu kulturowego.

Wydaje się, że nowe perspektywy rozwoju otworzyły się po pacyfikacji Pomorza, z którym omawiany ośrodek od dawna utrzymywał kontakty. Wtedy narodził się projekt utworzenia dwóch biskupstw na terenie Kujaw, z których jedno, z siedzibą w Kruszwicy, miało m.in. odpowiadać za przebieg misji na Pomorzu 


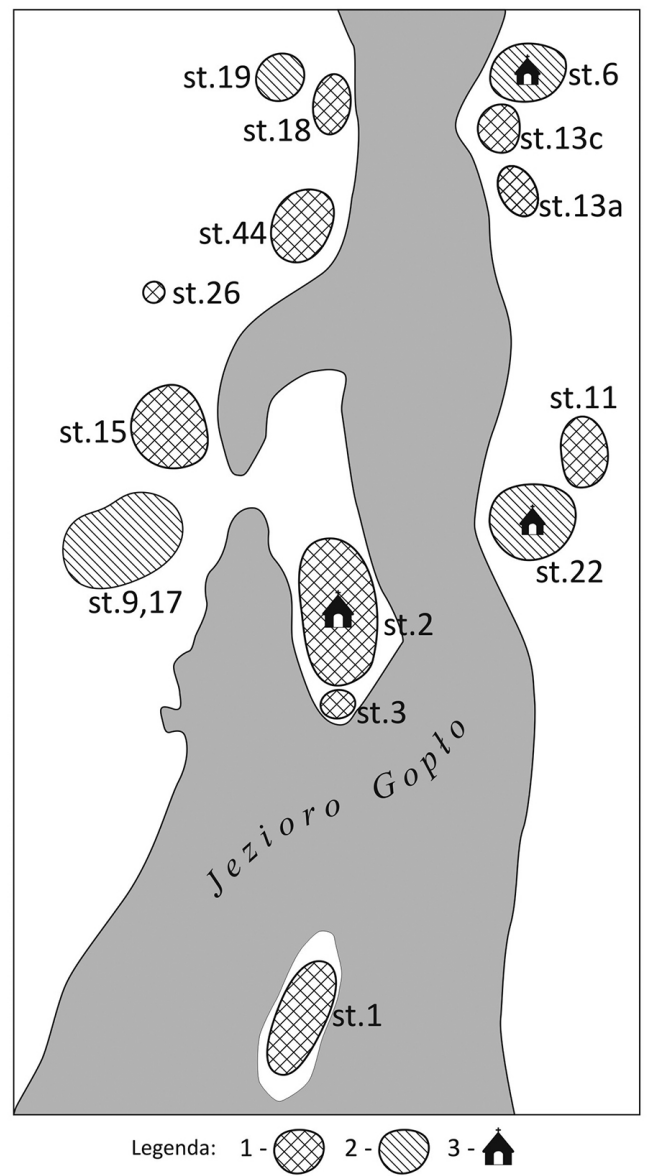

Ryc. 1. Kruszwica w XII i pierwszej połowie XIII wieku na podstawie badań Wojciecha Dzieduszyckiego (2008): 1 - osady; 2 - cmentarze; 3 - kościoły. Rys. B. Bednarczyk

Gdańskim (Labuda 1965). Ostatecznie zamiast dwóch, powstała jedna diecezja, kujawska, ze stolicą we Włocławku, przy czym za prawdopodobny należy uznać domysł, iż przynajmniej przez jakiś czas tę rolę spełniał nasz ośrodek (Michalski 1996, s. 107), dysponujący już kościołem św. Piotra wzniesionym na wschodnim brzegu Gopła. W tej samej części aglomeracji funkcjonowała również świątynia pw. św. Gotarda, natomiast na terenie dawnego grodu działała - założona jeszcze w czasach jego istnienia - kaplica św. Wita. Innym wydarzeniem, stanowiącym świadectwo ówczesnej rangi Kruszwicy, był zjazd książąt polskich oraz panów saskich w 1148 roku, odbyty przy okazji ślubu Judyty, córki Bolesława Krzywoustego z Ottonem, synem margrabiego brandenburskiego Albrechta Niedźwiedzia (por. m.in. Przybył 2018, tam wcześniejsza literatura). W następnych latach rosła polityczna rola Kruszwicy w księstwie kujawskim. Być może czynnik ten 
przyczynił się do przywrócenia jej funkcji grodowej. Nowy obiekt obronny, znacznie mniejszy, wzniesiono około połowy XIII wieku w południowej części dawnej warowni. W najbliższym sąsiedztwie funkcjonowała osada otwarta, działały też mosty i tradycyjne przeprawy oraz ustanowiona w 1252 roku komora celna, przy której istniało miejsce wymiany. Dalszy rozwój aglomeracji kruszwickiej doprowadził do uformowania w następnym stuleciu trzech centrów - miasta lokacyjnego z osadą i kościołem pw. św. Klemensa, zamku na wyspie grodowej oraz ośrodka kościelnego na wschodnim brzegu Gopła, zorganizowanego wokół kolegiaty św. Piotra (Dzieduszycki 2008, s. 427 i nn.).

W tym samym czasie ważne przeobrażenia dokonywały się w Lądzie nad Wartą. Tamtejszy gród, sięgający genezą czasów plemiennych, przeżył okres niezwykłego rozwoju w dobie pierwszych Piastów. Podobnie jak w Kruszwicy, czynnikiem, który umożliwił jego rozkwit, było korzystne usytuowanie przy ważnych szlakach wodnych i lądowych, nadające mu strategiczne znaczenie, wykorzystane zapewne w początkowej fazie ekspansji młodego państwa (Brzostowicz 2015a, s. 96). W pierwszej połowie XI wieku został spalony, lecz w następnych latach szybko go odbudowano. Gród zyskał wówczas potężniejsze fortyfikacje oraz szeroką fosę, połączoną z Wartą. Z badań archeologicznych, prowadzonych we wnętrzu grodziska wynika, że do około XI/XII lub początków XII stulecia obiekt był użytkowany jeszcze w tradycyjny sposób (Zeylandowa 1987). Prawdopodobnie wtedy wzniesiony został kościół grodowy, jeden z dwóch wymienionych w falsyfikatach dokumentów z rzekomo 1236 i 1240 roku (Brzostowicz 2016). Od tego momentu zaczął zmieniać się charakter warowni. W sąsiedztwie świątyni powstał cmentarz, co spowodowało likwidację zabudowy mieszkalnej i przeniesienie jej do części południowej, gdzie zajęła miejsce rozebranego wcześniej wału. Maria Zeylandowa (1987), główna badaczka grodziska, zauważyła, że w jego centrum pojawiły się paleniska, „w skład których wchodzą ciosy kamienne i płytki ceramiczne”. Równocześnie obiekty produkcyjne uruchomiono w obrębie sąsiadującej od południa osady. Dalsze zmiany zarejestrowano na drugim podgrodziu, położonym na północ od warowni. Tutaj, prawdopodobnie około połowy XII wieku, wzniesiono kolejną świątynię, przy której powstała następna nekropolia. Zaskakująca jest natomiast lokalizacja tego kościoła. Otóż zbudowano go przy krawędzi fosy, jakby nie przejmując się tym, że może zasłaniać przedpole i utrudniać obronę grodu. W kontekście XIII-wiecznych wojen o kasztelanię lądzką zastanawia również fakt zalegania w fosie wraku łodzi klepkowej, zatopionej, jak sądzę, w końcu XII stulecia (Brzostowicz 2008). Dochodzimy zatem do przekonania, że nie została oczyszczona, być może też nie dbano już o inne elementy fortyfikacji. Biorąc pod uwagę wszystkie wymienione działania, możemy skonstatować obniżenie walorów obronnych grodu oraz przekształcenie go w miejsce o charakterze religijnym i rzemieślniczym. Nie podtrzymuję jednak mojego wcześniejszego twierdzenia o powolnym zmierzchu znaczenia Lądu (Brzostowicz 2011, s. 115; 2015a, s. 100). Przeczy temu liczba oraz jakość znalezisk przedmiotów ruchomych, wskazujących m.in. na funkcjonowanie 
ośrodka wymiany dalekosiężnej, liczne elementy wspaniałej dekoracji świątyni grodowej, zdolność do ponoszenia świadczeń na rzecz arcybiskupa gnieźnieńskiego, potwierdzona bullą papieską z 1136 roku (KDW, 1, nr 7), czy wreszcie pełnienie, przynajmniej w sensie nominalnym, siedziby własnej kasztelanii.

Opisanym zjawiskom towarzyszyły zmiany w organizacji zaplecza grodu lądzkiego. W XII wieku rozpoczęła się eksploatacja wysoczyzny, rozciągającej się na prawym brzegu Warty, z którą należy łączyć szereg stanowisk archeologicznych odkrytych w pobliżu dzisiejszych wsi Lądek i Dolany. Pierwsza z nich, przez długi czas występująca w źródłach pisanych pod nazwą Kossol, działała przy kościele św. Mikołaja, wzniesionym zapewne już w XII stuleciu. Dodatkowo wzmianka o forum beatii Nicolai, wskazanym w dokumencie Kazimierza Kondratowica z 1250 roku (KDW, 1, nr 290) jako miejscu pierwszej, niestety nieudanej, lokacji miasta, informuje nas o istnieniu tu miejsca targowego. Obydwie osady, Kossol i Dolany, w przekonaniu Andrzeja M. Wyrwy (1995, s. 118; 2005, s. 77) weszły w skład pierwotnego uposażenia klasztoru cysterskiego w Lądzie, ufundowanego przez Mieszka III Starego. Ostatecznie, w pierwszej połowie XIII wieku wykształciła się prężna aglomeracja osadnicza (ryc. 2), obejmująca gród z dwoma podgrodziami, dwoma kościołami (św. Andrzeja i św. Piotra) oraz towarzyszącymi im cmentarzami, klasztor cysterski, osadę targową Kossol z kościołem św. Mikołaja, wieś Dolany, a także działające od dawna, niektóre nawet od czasów plemiennych, osiedla rozłożone na wydmach w pradolinie Warty. W trakcie wojen o kasztelanię lądzką, prawdopodobnie po zakończeniu ich pierwszej fazy w 1248 roku, pojawił się jeszcze inny gród (castellum), wzniesiony w nieznanym nam miejscu przez Kazimierza Kondratowica, niejako zastępujący starą warownię, przekazaną już cystersom (Szymczak 2009, s. 83 i nn.; Przybył 2012). Funkcjonował krótko, książę kujawski bowiem, pokonany przez Bolesława Pobożnego, zmuszony był go spalić (Kronika wielkopolska, rozdz. 122, 137). W 1269 roku podjęto udaną już lokację miasta, nazywanego później Kossol lub Ląd (Zierhoffer 2005; Brzostowicz 2018, s. 81), które pozostawało we włościach klasztoru. Z czasem, przy dużym oddziaływaniu czynników naturalnych, doszło do całkowitego opuszczenia wydm w pradolinie Warty i przeniesienia osadnictwa na wysoczyznę.

Śledząc przeobrażenia obydwu ośrodków w XII i XIII wieku, dostrzegamy charakterystyczne zjawiska towarzyszące rozkładowi organizacji grodowo-terytorialnej. W opinii Sławomira Moździocha (1990, s. 86-89 i 92; 2002, s. 215; 2015), który przestudiował ten proces na przykładzie Śląska, objawiał się on poprzez rozrzedzenie osadnictwa w obrębie wałów, pojawianie się śladów produkcji rzemieślniczej, rozrost cmentarzy przy kościołach grodowych oraz rozbiórkę fortyfikacji obronnych. Wszystkie wymienione symptomy wystąpiły w Kruszwicy i w Lądzie, przy czym w odróżnieniu od grodów śląskich, gdzie degradacja ich roli obronnej zaznaczyć się miała pod koniec XII i w XIII wieku, tamtejsze procesy zainicjowane zostały niemal o jedno stulecie wcześniej. Nie wiemy, czy należy je wiązać z wydarzeniami historycznymi, czy też zaobserwowana zbieżność 


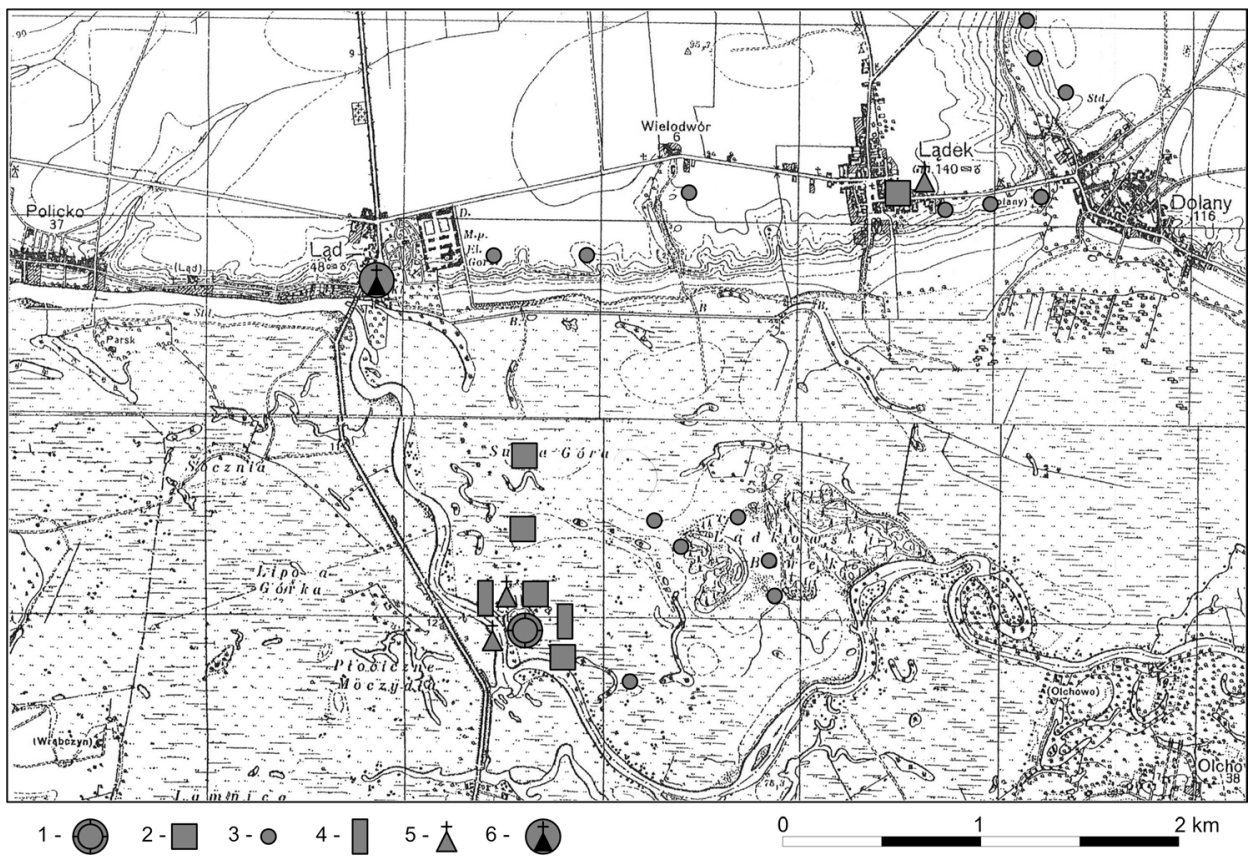

Ryc. 2. Ląd w XII i 1. połowie XIII wieku:

1 - gród; 2 - osady; 3 - ślady osadnictwa; 4 - cmentarze; 5 - kościoły; 6 - klasztor cysterski. Rys. T. Kasprowicz

miała charakter przypadkowy. O ile w Kruszwicy takie skojarzenia narzucają się w sposób automatyczny, to już w przypadku Lądu, przynajmniej w świetle naszej obecnej wiedzy, nie mają one zastosowania. Co więcej, budowa kościoła w obrębie warowni około XI/XII wieku, która zdezorganizowała jej dotychczasowe rozplanowanie, bardziej świadczy o wzmocnieniu niż obniżeniu rangi owego ośrodka. Niemniej to właśnie wtedy doszło do rozbiórki wału od strony południowej i pojawieniu się w tym miejscu budynków mieszkalnych. Możliwe, iż, jak uważała Maria Zeylandowa (1987), wiązało się to $\mathrm{z}$ włączeniem pobliskiej osady do poszerzonego w taki sposób grodu, lecz jej domysły nie znalazły potwierdzenia w postaci odkrycia pozostałości rzekomo przesuniętych na południe fortyfikacji. Dochodzimy zatem do przekonania, że przeobrażenia zachodzące w Lądzie, mimo podobieństw, miały inne podłoże niż w Kruszwicy. Możemy też przewrotnie spytać, czy na zmianę charakteru nadgoplańskiego grodu rzeczywiście wpłynęły konsekwencje bitwy przegranej w 1096 roku? Niezależnie od pojawiających się rozterek, należy skonstatować, iż w jednym czasie w obydwu odległych od siebie ośrodkach rozpoczął się nowy etap ich rozwoju.

W literaturze przedmiotu akcentuje się zmianę organizacji i podstaw utrzymywania sił zbrojnych jako jednego z czynników wpływających od XII wieku na 
odmienny obraz grodów od tego, który znamy z czasów wczesnopiastowskich. Związany z tym proces opuszczania warowni przez wojów i osiedlania w nadanych im zapewne ziemiach jest uchwytny zarówno w źródłach pisanych (por. Jurek 2014, s. 82 i nn.), jak i archeologicznych (Brzostowicz 2015b, s. 62). Czy stwierdzony zatem fakt zaniedbywania, a nawet rozbierania fortyfikacji grodowych został spowodowany brakiem stałej obecności zbrojnych załóg? Wydaje się, że nie, nadal wymagany był obowiązek stróży (por. np. KDW, 1, nr 486; por. też Jurek 2014, s. 83). Co więcej, w niektórych warowniach (np. w Poznaniu, Śremie czy Sandomierzu - por. Kronika wielkopolska, rozdz. 87; Dzieduszycki i Fogel 1980, s. 85; Buko 1998, s. 92), niemal w przededniu lokacji tamtejszych miast dalej dokonywano napraw umocnień obronnych, a część starych grodów przetrwała do pierwszej połowy XIV wieku, wykazując jeszcze sporą przydatność w działaniach wojennych. Niemniej trudno odrzucić nakreślony przez Tomasza Jurka (2014, s. 83) obraz XII-XIII-wiecznego grodu, pozbawionego załogi oraz części mieszkańców, okazjonalnie odwiedzanego przez przypisanego mu urzędnika, a nader wyjątkowo przez księcia. Zaniedbane fortyfikacje, powiększający się cmentarz przy kościele grodowym i działające aktywnie warsztaty produkcyjne musiały zniechęcać wybitne osobistości do dłuższego pobytu w takim miejscu. Zapewne dlatego T. Jurek (2014, s. 80 i nn.) uznał, że ówczesne grody nie pełniły już funkcji rezydencjonalnych. Analizując itineraria piastowskich książąt, dostrzegł, iż często zatrzymywali się w nic nieznaczących miejscowościach, rozbijając obozy w polach ,jak Numida". Ale też wymieniony badacz, posługujący się przykładem Łęczycy, przestrzega przed zbyt pochopnym wyciąganiem wniosków, zwłaszcza wysuwaniem sugestii o spadku rangi danego ośrodka. Dodam, że przedstawiane tu przypadki Kruszwicy i Lądu również dowodzą czegoś przeciwnego.

Interesującym zjawiskiem jest niemal niezakłócony rozwój, a nawet rozkwit produkcji rzemieślniczej w omawianych ośrodkach. Postępował on mimo odpływu wojów, urzędników grodowych i lokalnych elit będących dotąd najwdzięczniejszymi odbiorcami wyrobów powstających w tamtejszych warsztatach. W tym kontekście mało znaczący jest fakt czasowego obniżenia jakości wytworów garncarskich w Kruszwicy, spowodowany wymianą fachowców, skoro odkrywamy ślady działań zapobiegających zanikowi tej dziedziny rzemiosła. Spadek wartości grodów nie wpłynął zatem na ustanie koniunktury gospodarczej, ta natomiast rozwijała się dzięki korzystnemu usytuowaniu obydwu ośrodków przy ważnych szlakach komunikacyjnych i dalszemu funkcjonowaniu punktów targowych. Dzięki temu zarówno Kruszwica, jak i Ląd nadal były miejscami tętniącymi życiem. Co więcej, obserwujemy rozrost aglomeracji osadniczych, prowadzący do - częściowego lub całkowitego - przeorganizowania ich przestrzeni. Na przebieg tego procesu istotny wpływ wywarły również czynniki naturalne, konkretnie zaś transgresja wód Gopła w Kruszwicy oraz Warty w Lądzie. Natomiast niezwykle interesujący jest fakt, zaobserwowany także w innych ośrodkach, ekspansji działalności rzemieślniczej na tereny opuszczonych przez swe załogi grodów. Nie wiemy, czy to zjawisko 
następowało w sposób żywiołowy, czy też było efektem odgórnych zarządzeń, zabezpieczających interesy władzy książęcej, której owe warownie nadal podlegały. Równie prawdopodobne jest podporządkowanie działających tam fachowców przedstawicielom duchowieństwa, związanym z kościołami grodowymi.

Tymczasem obecność stosunkowo licznych świątyń, po trzy w każdym z omawianych ośrodków, stanowi kolejne świadectwo ich ówczesnego znaczenia. Z pewnością wspaniałością, bogactwem i rangą wyróżniał się kościół, a z czasem kolegiata św. Piotra w Kruszwicy, zaliczana dziś do najwspanialszych pomników architektury romańskiej w Polsce. Niewykluczone, iż budowę tego obiektu podjęto z myślą ustanowienia tu biskupstwa. Nietuzinkowy był zapewne kościół grodowy w Lądzie. Jakkolwiek nie dysponujemy żadnymi danymi na temat wielkości i planu wspomnianej budowli, to znaleziska elementów jej wystroju z przedstawieniami odwołującymi się do symboliki władzy królewskiej (Zeylandowa 1992; Brzostowicz 2016, s. 266 i nn.) pozwalają sądzić, iż ten ośrodek cieszył się dużym zainteresowaniem władców piastowskich. Niezaprzeczalnym przejawem owej troski było ufundowanie przez Mieszka III Starego klasztoru cysterskiego, który stanął na północno-zachodniej rubieży tutejszej aglomeracji. Warto też zwrócić uwagę na dwa inne kościoły, a mianowicie św. Gotarda w Kruszwicy i św. Mikołaja w Ląd$\mathrm{ku}$, nastawione, jak wyraźnie wynika z ich lokalizacji, na obsługę podróżnych, przede wszystkim kupców, dokonujących transakcji na miejscowych targach. Te z kolei mogły się rozwijać dzięki dogodnemu położeniu przy szlakach handlowych. Nie ulega natomiast wątpliwości, że dzięki swoim obiektom sakralnym omawiane ośrodki stały się ważnymi centrami życia religijnego. Z pewnością odegrały dużą rolę w nasilającej się wówczas chrystianizacji całego kraju. Wymierne efekty tego procesu odnotowujemy w Lądzie, gdzie na tamtejszych nekropoliach przykościelnych, które zastąpiły cmentarz funkcjonujący w XI wieku (por. Samela 2011), stwierdzono znikomy udział pochówków z wyposażeniem (Dębska-Luty i Lipińska 1986, s. 76).

Przykłady Kruszwicy i Lądu wskazują, że w XII i XIII wieku dawny ośrodek grodowy, mimo znamion upadku warowni, wokół której ongiś się zorganizował, mógł dalej się rozwijać i pozostawać centrum życia politycznego, społecznego, religijnego, gospodarczego i kulturalnego, ciesząc się przy tym niezmiennym zainteresowaniem władcy. W pewnym sensie możemy mówić o ich miejskim charakterze, oczywiście w innym znaczeniu od tego, jakie reprezentowały powstające już organizmy na mocy odrębnych aktów prawnych. Co więcej, w niektórych aspektach różniły się od grodowych zespołów osadniczych, czy też emporiów rzemieślniczo-handlowych, znanych z wcześniejszych stuleci, którym nierzadko przypisuje się podobne cechy ${ }^{1}$. Nie były fenomenem, ponieważ takich

${ }^{1}$ W tym miejscu rezygnuję z przytaczania bogatej literatury odnoszącej się do dyskusji na temat miast, ich genezy, kryteriów wyróżniania, funkcji oraz zasadności przypisywania miejskich cech rozmaitym ośrodkom przedlokacyjnym, w których koncentrowała się działalność rzemieślnicza i handlowa. 
przykładów jak one znajdujemy wiele, ale też nie stanowiły wzorca losów każdego innego współczesnego im ośrodka, ułatwiającego studiowanie przedstawionego problemu. Stan, jaki wytworzył się w Kruszwicy i Lądzie, można nazwać etapem pośrednim w ich rozwoju od grodu do miasta lokacyjnego, przy czym należy zastrzec, że jest on właściwy tylko im oraz miejscom rozwijającym się w podobny sposób. Nie stanowił więc zasady. Już przykład Giecza wskazuje, że ich losy mogły potoczyć się w innym kierunku. Zresztą, następne lata okazały się dla nich mniej łaskawe. Wojny o kasztelanię lądzką oraz jej czasowa okupacja przez Kazimierza Kondratowica doprowadziły do przesunięcia szlaku gnieźnieńsko-kaliskiego bardziej na zachód oraz rozwoju położonych przy nim Pyzdr, które szybko zdystansowały stary piastowski ośrodek (Brzostowicz 2018). Konsekwencją było zmniejszenie ruchu na dawnej drodze, skutkujące zapewne nieudaną próbą lokacji Lądka (Kossol) w 1250 roku. Kolejna, przeprowadzona w 1269 roku, zakończyła się już powodzeniem, lecz głównym centrum życia stał się klasztor cysterski, który ostatecznie przejął teren opuszczonego grodu. Niewątpliwie lepiej powiodło się Kruszwicy, ale i ona z czasem spadła do rangi ośrodka o lokalnym znaczeniu.

Wróćmy jednak do obrazu omawianych aglomeracji osadniczych z XII i XIII wieku. Odnosimy wrażenie, że najsłabszym elementem każdej z nich był gród. Jak pamiętamy, w przekonaniu Wojciecha Dzieduszyckiego warownia w Kruszwicy miała już nie funkcjonować, natomiast analogiczny obiekt w Lądzie jawi się nam jako zaniedbany. Obydwa miejsca zmieniły swój charakter - zajęte przez warsztaty rzemieślnicze oraz kościoły z rozrastającymi się nekropoliami w niczym nie przypominały tego, czym były w czasach wczesnopiastowskich. Mimo to nasze ośrodki wciąż cieszyły się zainteresowaniem książąt dzielnicowych, utrzymujących związane z nimi urzędy kasztelanów, organizujących tam ważne wydarzenia polityczne (np. zjazd w Kruszwicy w 1148 roku), snujących powiązane z nimi śmiałe projekty (np. utworzenia biskupstwa kruszwickiego), dokonujących szczytnych fundacji (np. klasztoru lądzkiego), czy też toczących o nie zacięte wojny (np. o kasztelanię lądzką w XIII wieku). Niewątpliwie protekcja władcy, obok wielu innych czynników, przede wszystkim zaś dogodnego usytuowania przy ruchliwych szlakach handlowych, sprzyjała ich ówczesnemu rozwojowi. Działo się tak mimo dostrzegalnych przez badaczy symptomów rozkładu organizacji grodowo-terytorialnej. Tymczasem wydaje się, że ona nadal funkcjonowała, może w zmodyfikowanej postaci (por. Fokt 2019), choć wiele warowni upodobniło się do omawianych obiektów, inne już zostały opuszczone, inne jeszcze przekazane klasztorom, instytucjom kościelnym czy rodom rycerskim, a w pejzażu ziem polskich pojawiały się już elementy nowej rzeczywistości - niewielkie gródki-zamki oraz miasta lokacyjne, współistniejące gdzieniegdzie ze starszymi formami osadniczymi. Zmiany w tym zakresie następowały powoli i przebiegały zgodnie z wolą władców dzielnicowych, decydujących o dalszych losach poszczególnych ośrodków (Brzostowicz 2014, s. 392 i nn.; 2015b, s. 68). Zdeterminowały one również dalsze przekształcenia 
w Kruszwicy i Lądzie, z których pierwsza, wpleciona poprzez swój zamek w system obronny państwa, pozostała królewska, drugi zaś przeszedł w ręce cystersów, dających później liczne świadectwa lojalności wobec polskich monarchów.

\section{BIBLIOGRAFIA}

Brzostowicz M. 2005, Gród wczesnośredniowieczny w Lądzie nad Wartą w świetle badań archeologicznych, w: M. Brzostowicz, H. Mizerska, J. Wrzesiński (red.), Ląd nad Wartą. Dziedzictwo kultury słowiańskiej i cysterskiej, Poznań-Ląd, s. 47-60.

- 2008, Ląd na szlakach wodnych wczesnośredniowiecznej Stowiańszczyzny. Przyczynek do badań, w: M. Bogacki, M. Franz, Z. Pilarczyk (red.), Kultura ludów Morza Bałtyckiego, t. 1. Starożytność i średniowiecze, Toruń, s. 262-270.

- 2011, Badania archeologiczne nad zapleczem grodziska wczesnośredniowiecznego w Lądzie, pow. stupecki, „Fontes Archaeologici Posnanienses”, t. 47, s. 107-127.

- 2014, Schyłek organizacji grodowej w Wielkopolsce, w: K. Czapla, K. Chrzan. S. Moździoch, Funkcje grodów w państwach wczesnośredniowiecznej Europy środkowej. Społeczeństwo, gospodarka i ideologia, Wrocław-Głogów, s. 381-399.

- 2015a, Ląd i ziemia nad Warta, w: S. Moździoch (red.), O rzece $i$ wodzie $w$ życiu codziennym człowieka średniowiecza, „Spotkania Bytomskie”, t. 8, Wrocław, s. 93-111.

- 2015b, Wielkopolska $w$ XII i XIII wieku w świetle badań archeologicznych, „Fontes Archaeologici Posnanienses", t. 51, s. 55-72.

- 2016, Kościoły grodowe w Lądzie nad Warta, w: M. Rębkowski (red.), Kościoły w dobie chrystianizacji, „Wolińskie Spotkania Mediewistyczne”, t. 3, Szczecin, s. 255-279.

- 2018, Archeologiczne przyczynki do studiów nad początkami miast w Wielkopolsce. Przykład Lądka, Pyzdr i Wrześni, w: H. Machajewski (red.), Archeologia dawnego osadnictwa Wielkopolski, Poznań, s. 81-103.

Buko A. 1998, Początki Sandomierza, Warszawa.

Dębska-Luty K., Lipińska A. 1986, Wczesnośredniowieczne cmentarzyska szkieletowe w Lądzie, woj. Konin, w: L. Krzyżaniak (red.), Wczesnośredniowieczne cmentarzyska szkieletowe w Lądzie, woj. Konin, Biblioteka „Fontes Archaeologici Posnanienses”, t. 7, Poznań, s. 13-86.

Dzieduszycka B. 1995, Z badań nad kształtowaniem się osadnictwa wczesnośredniowiecznego na przykładzie regionu nadgoplańskiego, regionu zachodnich Pałuk i regionu środkowego biegu Baryczy, „Slavia Antiqua”, t. 35, s. 69-99.

Dzieduszycki W., 1982, Wczesnomiejska ceramika kruszwicka $w$ okresie od 2 połowy X w. do połowy $X I V$ w., Wrocław.

- 1984, Socjotopograficzne przeobrażenia wczesnośredniowiecznych miast polskich (model kruszwicki), „Kwartalnik Historii Kultury Materialnej”, t. 32 (1), s. 3-21.

- 2008, Kruszwica - piastowska domena nad Gopłem, w: M. Kobusiewicz (red.), Pradzieje Wielkopolski. Od epoki kamienia do średniowiecza, Poznań, s. 397-429.

- 2015, Przemiany Kujaw w XII-XIII wieku, „Fontes Archaeologici Posnanienses”, t. 51, s. 73-81.

Dzieduszycki W., Fogel J. 1980, Gród wczesnośredniowieczny w Śremie, „Slavia Antiqua”, t. 26, s. 33-91.

Fokt K. 2019, Organizacja grodowa a grodowo-kasztelańska na przykładzie Śląska, „Historia Slavorum Occidentis", nr 2 (21), s. 96-115.

Gall = Anonim tzw. Gall. Kronika polska, tłum. R. Grodecki, oprac. M. Plezia, Wrocław 1996.

Jurek T. 2014, Pierwsze wieki historii Łęczycy, w: R. Grygiel, T. Jurek (red.), Początki Łęczycy, t. 3, Łódź, s. 7-196.

KDW = Kodeks Dyplomatyczny Wielkopolski, t. 1, Poznań 1877.

Kronika wielkopolska $=$ Kronika wielkopolska, tłum. K. Abgarowicz, oprac. B. Kürbisówna, Warszawa 1965.

Labuda G. 1965, Początki diecezjalnej organizacji kościelnej na Pomorzu i Kujawach w XI-XII wieku, „Zapiski Historyczne”, t. 33/3, s. 19-60. 
Michalski M. 1996, Ustanowienie i wczesne dzieje biskupstwa kujawskiego, „Scripta Minora”, t. 1, s. 83-108.

Moździoch S. 1990, Organizacja gospodarcza państwa piastowskiego na Śląsku. Studium archeologiczne, Wrocław.

- 2002, Castrum munitissimum Bytom. Lokalny ośrodek władzy w państwie wczesnopiastowskim, Warszawa.

- 2015, Przemiany XII-XIII wieku na Śląsku w świetle badań grodów kasztelańskich, „Fontes Archaeologici Posnanienses", t. 51, s. 83-96.

Przybył M., 2012, Problem identyfikacji i lokalizacji XIII-wiecznego ośrodka kasztelanii lądzkiej w świetle badań historycznych $i$ archeologicznych, w: M. Brzostowicz, M. Przybył, D.A. Sikorski (red.), Archaeologia versus historiam - historia versus archaeologiam, czyli jak wspólnie poznawać średniowiecze, Poznań, s. 175-192.

- 2018, Kontekst polityczny zjazdu w Kruszwicy w 1148 roku, w: M. Brzostowicz, T. Kasprowicz, M. Przybył, J. Wrzesiński (red.), Od Popiela do Kazimierza Wielkiego. Księga Jubileuszowa Profesora Wojciecha Dzieduszyckiego, Poznań, s. 91-101.

Samela K., 2011, Cmentarzysko wczesnośredniowieczne w Ladzie nad Warta, stan. 9, pow. stupecki, woj. wielkopolskie, „Fontes Archaeologici Posnanienses”, t. 47, s. 129-177.

Szymczak J., 2009, Piętnastoletnia wojna o Ląd i kasztelanię lądzka (1247-1261) czyli konflikt o posag księżniczki śląskiej Konstancji, w: M. Brzostowicz, M. Przybył, J. Wrzesiński (red.), Miłość, damy i rycerze, Poznań-Ląd, 69-84.

Wyrwa A. M., 1995, Procesy fundacyjne wielkopolskich klasztorów cysterskich linii altenberskiej. Łekno - Ląd-Obra, Poznań.

- 2005, Zakon cystersów i jego klasztor w Lądzie. Wybrane problemy z dziejów, w: M. Brzostowicz, H. Mizerska, J. Wrzesiński (red.), Lad nad Warta. Dziedzictwo kultury słowiańskiej i cysterskiej, Poznań-Ląd, s. 61-99.

Zeylandowa M. 1987, Grodzisko wczesnośredniowieczne w Lądzie, Poznań (maszynopis w bibliotece naukowej Muzeum Archeologicznego w Poznaniu).

- 1992, Nowe relikty architektury romańskiej z Lądu, woj. konińskie, „Fontes Archaeologici Posnanienses", t. 37, s. 106-109.

Zierhoffer Z., 2005, Lądek, w: K. Rymut (red.), Nazwy miejscowe Polski. Historia-pochodzenie-zmiany, Kraków, s. 37. 